\title{
UPAYA MENINGKATKAN AKTIVITAS DAN HASIL BELAJAR BIOLOGI MELALUI GROUP INVESTIGATION (GI)
}

\author{
Teguh Supriadi \\ Muhfahroyin \\ Pendidikan Biologi FKIP Universitas Muhammadiyah Metro Lampung \\ E-mail: teguhsupriadi17@yahoo.com
}

\begin{abstract}
Learning achievement is a students capability while and after accept learning experience learning. Learning process involved students activity is needed, so that to give the meaning and the real learning of students. GI cooperative learning model is a learning model involved whice all of students activity in learning process. In learning process the students find knowledge independenly because they are active and teacher just only as a facilitator. The conclusion of this research is the GI cooperative learning model can improve the result of study students XI IPA SMA Kosgoro Sekampung school year 2011/2012 from pre-classroom action research to the second cycle for 47,37\% and researcher suggests that the GI cooperative learning model can be used to increase learning achievement of biology learning.
\end{abstract}

Kata Kunci: Group Investigation, Aktivitas Belajar, Hasil Belajar

Hasil belajar merupakan kemampuan yang dimiliki siswa setelah menerima pengalaman belajar. Pembelajaran yang melibatkan keaktifan siswa perlu dilakukan, sehingga akan memberikan makna dan arti belajar yang sesungguhnya bagi siswa. Model pembelajaran kooperatif tipe GI merupakan model pembelajaran yang secara keseluruhan melibatkan keaktifan siswa pada saat proses pembelajaran. Pada saat proses pembelajaran siswa mencari pengetahuan secara mandiri karena siswa berperan aktif dan guru hanya sebagai fasilitator. Kesimpulan penelitian ini adalah model pembelajaran kooperatif tipe GI dapat meningkatkan hasil belajar siswa kelas XI IPA SMA Kosgoro Sekampung tahun pelajaran 2011/2012 dari pra-PTK kesiklus II sebesar 47,37\% dan saran peneliti bahwa model pembelajaran kooperatif tipe GI dapat digunakan untuk meningkatkan hasil belajar biologi.
Pendidikan sebagai proses pembelajaran bertujuan untuk mengembangkan seluruh potensi yang ada pada diri siswa secara optimal baik kognitif, afektif maupun psikomotorik. Salah satu masalah pembelajaran di sekolah adalah banyaknya siswa yang memperoleh hasil belajar yang rendah. Masalah pembelajaran pada umumnya terjadi di kelas, kelas dalam hal ini berarti segala kegiatan yang dilakukan guru dan anak didiknya di dalam suatu ruangan dalam melaksanakan proses pembelajaran (Sanjaya, 2010). Pembelajaran di kelas mencakup interaksi guru dan siswa, teknik dan strategi pembelajaran, dan implementasi kurikulum serta evaluasinya.

SMA Kosgoro Sekampung merupakan salah satu sekolah swasta yang memiliki input atau masukan siswa yang memiliki hasil belajar yang bervariasi. Hasil belajar yang bervariasi ini menunjukkan bahwa peran serta dan keaktifan siswa dalam kegiatan pembelajaran sangat beranekaragam. Menurut hasil observasi 
kelas dan keterangan guru mata pelajaran biologi di SMA Kosgoro Sekampung Tahun Pelajaran 2011/2012 menunjukkan bahwa kelas tersebut terdiri dari siswa yang heterogen berdasarkan hasil belajar, budaya dan tingkat sosial ekonominya. Proses pembelajaran yang berlangsung cenderung menggunakan model pembelajaran yang kurang melibatkan keaktifan siswa, sehingga siswa kurang optimal mengembangkan kemampuan yang dimilikinya dan termotivasi dalam proses pembelajaran. Akibatnya berpengaruh terhadap hasil belajar. Berdasarkan pertimbangan tersebut, maka diperlukan model pembelajaran yang mampu melibatkan peran serta siswa secara menyeluruh sehingga kekuatan proses belajar tidak hanya didominasi oleh siswasiswa tertentu saja. Pemilihan model pembelajaran tersebut diharapkan dapat meningkatkan peran serta dan keaktifan siswa dalam mempelajari dan menelaah ilmu. Dalam tabel 1 dapat dilihat hasil belajar siswa pada pra-PTK.

Tabel 1: Ketuntasan Belajar Siswa Kelas XI IPA SMA Kosgoro Sekampung Tahun Pelajaran 2011/2012

\begin{tabular}{|c|c|c|c|}
\hline Nilai & Kriteria & $\begin{array}{c}\text { Jumlah } \\
\text { Siswa } \\
\end{array}$ & $\%$ \\
\hline$\geq 70$ & Tuntas & 13 & $34,21 \%$ \\
\hline$<70$ & $\begin{array}{l}\text { Belum } \\
\text { tuntas }\end{array}$ & 25 & $65,79 \%$ \\
\hline & Jumlah & 38 & $100 \%$ \\
\hline
\end{tabular}

Sumber: Nilai Ulangan Harian Biologi Siswa Kelas XI IPA SMA Kosgoro Sekampung

Data penilaian dari nilai ulangan harian semester genap pada mata Pelajaran Biologi, siswa yang mendapat nilai kurang dari $<70$ sebanyak 25 siswa (65,79\%), dan yang mendapat nilai antara $\geq 70$ yaitu sebanyak 13 siswa (34,21\%). Kriteria Ketuntasan Minimum (KKM) untuk mata Pelajaran Biologi SMA Kosgoro Sekampung yaitipo.

Maka ketuntasan belajar siswa tersebut belum mencapai standar yang diharapkan. Berkaitan dengan permasalahan yang terjadi, maka perlu diadakan proses pembelajaran yang menekankan titik aktivitas belajar siswa yang lebih aktif dan menyenangkan dan menciptakan suasana belajar dan akan memberikan dampak positif pada hasil belajar siswa dengan mengalami peningkatan pada hasil belajarnya.

Model pembelajaran kooperatif tidak sama dengan sekedar belajar dalam kelompok. Ada unsur-unsur dasar model pembelajaran kooperatif yang membedakannya dengan pembagian kelompok yang dilakukan asal-asalan. Pelaksanaan prosedur model pembelajaran kooperatif dengan benar akan memungkinkan guru mengelola kelas lebih efektif. Model pembelajaran kooperatif akan dapat menumbuhkan pembelajaran efektif yaitu pembelajaran yang bercirikan: 1) "memudahkan siswa belajar" sesuatu yang "bermanfaat" seperti fakta, ketrampilan, nilai, konsep, dan bagaimana hidup serasi dengan sesama; 2) pengetahuan, nilai, dan keterampilan diakui oleh mereka yang berkompeten menilai. Suprijono (2009) menyatakan bahwa tidak semua belajar kelompok bisa dianggap model pembelajaran kooperatif. Untuk mencapai hasil yang maksimal, lima unsur dalam model pembelajaran kooperatif harus diterapkan. Lima unsure tersebut adalah: (1) positive interpendence (saling ketergantungan positif); (2) personal responsibility (tanggung jawab perseorangan); (3) face to face promotive interaction (interaksi promotif); (4) interpersonal skill (komunikasi antaranggota); (5) group processing (pemrosesan kelompok).

Model pembelajaran kooperatif tipe GI adalah salah satu model pembelajaran kooperatif yang dapat membangun kerjasama antara guru dan siswa dalam pembelajaran. Prosedur dalam perencanaan bersama didasarkan pada pengalaman masing-masing siswa, sesuai dengan kapasitas dan kebutuhan. Siswa aktif berpartisipasi dalam semua aspek, membuat keputusan untuk menetapkan arah tujuan yang mereka kerjakan. Kelompok berfungsi sebagai 
wahana dalam berinteraksi sosial. Perencanaan kelompok dapat menjamin keterlibatan semua siswa secara maksimal dalam penggunaan tipe ini.

Dalam model pembelajaran kooperatif tipe GI memiliki 3 konsep utama, yaitu: 1) penelitian yaitu proses dimana siswa dirangsang dengan menghidupkan pada suatu masalah. Siswa merasa dirinya perlu memberikan reaksi terhadap masalah yang dianggap perlu untuk diselesaikan. Masalah ini didapat dari siswa sendiri atau diberikan oleh guru; 2) pengetahuan yaitu pengalaman yang tidak dibawa sejak lahir namun diperoleh siswa melalui pengalaman baik secara langsung maupun tidak langsung; 3) dinamika kelompok, menunjukkan suasana yang menggambarkan sekelompok individu yang saling berinteraksi mengenai sesuatu yang sengaja dilihat atau dikaji bersama dengan berbagai ide dan pendapat serta saling tukar-menukar pengalaman dan saling berargumentasi.

Lie 2004) dan Sharan (dalam Trianto, 2010) membagi langkahlangkah pelaksanaan model pembelajaran kooperatif tipe GI dalam 6 fase yaitu:

a. Memilih topik. Siswa memilih subtopik khususnya di dalam suatu daerah masalah umum yang biasanya ditetapkan oleh guru.

b. Perencanaan kooperatif. Siswa dan guru merencanakan prosedur pembelajaran, tugas dan tujuan khusus yang konsisten dengan subtopik yang telah dipilih.

c. Implementasi. Siswa menerapkan rencana yang telah mereka kembangkan di dalam tahap kedua.

d. Analisis dan sintesis. Siswa mengalalisis dan mensintesis informasi yang diperoleh pada tahap ketiga dan merencanakan bagai mana informasi tersebut diringkas dan disajikan dengan cara yang menarik sebagai bahan untuk dipresentasikan.

e. Presentasi hasil final. Setiap kelompok telah siap memberikan hasil akhir di depan kelas dengan berbagai bentuk presentasi. Diharapkan dari penyajian presentasi yang beraneka ragam tersebut, kelompok lain dapat aktif mengevaluasi kejelasan dari laporan setiap kelompok dengan melakukan tanya jawab.

f. Evaluasi. Pada tahap ini siswa memberikan tanggapan dari masing-masing topik pengalaman aktif mereka. Guru dan siswa lain berkolaborasi mengevaluasi proses belajar sehingga semua siswa diharapkan menguasai semua sub topik yang disajikan.

Pentingnya model pembelajaran kooperatif tipe GI yaitu:

a. Pertama, dalam model pembelajaran kooperatif tipe GI berpusat pada siswa, guru hanya bertindak sebagai fasilitator atau konsultan sehingga siswa berperan aktif dalam pembelajaran.

b. Kedua, pembelajaran yang dilakukan membuat suasana saling bekerjasama dan berinteraksi antar siswa dalam kelompok tanpa memandang latar belakang, setiap siswa dalam kelompok memadukan berbagai ide dan pendapat, saling berdiskusi dan beragumentasi dalam memahami suatu pokok bahasan serta memecahkan suatu permasalahan yang dihadapi.

c. Ketiga, model pembelajaran kooperatif tipe GI siswa dilatih untuk memiliki kemampuan yang baik dalam berkomunikasi, semua kelompok menyajikan suatu presentasi yang menarik dari 
berbagai topik yang telah dipelajari, semua siswa dalam kelas saling terlihat dan mencapai suatu perspektif yang luas mengenai topik tersebut.

d. Keempat, adanya motivasi yang mendorong siswa agar aktif dalam proses belajar mulai dari tahap pertama sampai tahap akhir pembelajaran (Rusman, 2010).

Aktivitas siswa sebagai keterlibatan siswa dalam bentuk sikap, pikiran, perbuatan dan aktivitas dalam kegiatan pembelajaran guna menunjang keberhasilan proses pembelajaran dan memperoleh manfaat dari kegiatan tersebut sehingga hasil belajar dapat tercapai. Menurut Anderson dan Krathwohl (2001) berkenaan dengan hasil belajar intelektual yang terdiri dari enam aspek. Enam aspek itu yaitu:

a. Mengingat: Mengambil, mengingat, atau mengenali pengetahuan dari memori. Mengingat adalah ketika memori digunakan untuk menghasilkan definisi, fakta, atau daftar, atau membacakan atau mengambil materi.

b. Memahami: Membangun makna dari berbagai jenis fungsi yang akan mereka tulis atau grafik pesan kegiatan, mencontohkan, mengklasifikasi, meringkas, menyimpulkan, membandingkan, dan menjelaskan.

c. Menerapkan: Melaksanakan atau menggunakan prosedur melalui pelaksana, atau menerapkan. Menerapkan terkait dan merujuk pada situasi di mana bahan belajar yang digunakan melalui produk seperti model, presentasi, wawancara atau simulasi.

d. Menganalisis: Breaking bahan atau konsep ke dalam bagian, menentukan bagaimana bagianbagian saling berhubungan atau satu sama lain atau ke struktur keseluruhan atau tujuan. Ketika seseorang menganalisis dia bisa menggambarkan hal ini fungsi mental dengan menciptakan spreadsheet, survei, grafik, atau diagram, atau representasi grafis.

e. Mengevaluasi: Membuat penilaian berdasarkan kriteria dan standar melalui memeriksa dan mengkritisi. Kritik, rekomendasi, dan laporan adalah beberapa produk yang dapat dibuat untuk menunjukkan proses-proses evaluasi.

f. Membuat: Menempatkan elemen bersama-sama untuk membentuk satu kesatuan yang koheren atau fungsional; reorganisasi elemen ke pola baru atau struktur melalui menghasilkan, perencanaan, atau menghasilkan.

Kegiatan pembelajaran dikatakan efisien jika hasil belajar yang diinginkan dapat dicapai dengan usaha yang sekecil mungkin. Perwujudan perilaku belajar biasanya dapat dilihat dari adanya perubahan-perubahan kebiasaan, keterampilan, dan pengetahuan, sikap dan kemampuan yang biasanya disebut sebagai hasil belajar. Menurut Sudjana (199) hasil belajar memuat kemampuan yang dimiliki siswa setelah ia menerima pengalaman belajar.

Berdasarkan latar belakang dan identifikasi masalah tersebut maka dapat dirumuskan masalah sebagai berikut apakah model pembelajaran kooperatif tipe GI dapat meningkatkan hasil belajar siswa mata Pelajaran Biologi Pokok bahasan Reproduksi pada kelas XI IPA SMA Kosgoro Sekampung Tahun Pelajaran 2011 /2012?. Penelitian ini bertujuan untuk Meningkatkan hasil belajar siswa pada mata pelajaran Biologi melalui model pembelajaran kooperatif tipe GI. Manfaat yang diharapkan dari penelitian ini antara lain: 
1) Bagi siswa yaitu: Meningkatkan aktifitas siswa dalam pembelajaran biologi, mendapatkan pengalaman pembelajaran dengan model pembelajaran kooperatif tipe GI, dan meningkatkan kualitas hasil belajar siswa dalam Pembelajaran Biologi; 2) Bagi guru yaitu: Mampu meningkatkan mutu proses dan hasil pembelajaran dan memberikan masukan kepada guru tentang model pembelajaran efektif untuk meningkatkan aktivitas dan hasil belajar siswa; dan 3) Memperoleh dan menambah wawasan, pengetahuan serta keterampilan peneliti khususnya terkait dengan penelitian yang menggunakan model pembelajaran kooperatif tipe GI.

\section{METODE}

Penelitian ini merupakan
penelitian tindakan kelas yang
dilaksanakan pada semester genap tahun
pelajaran 2011/2012. Penelitian ini
dilaksanakan untuk standar kompetensi, yaitu menjelaskan struktur dan fungsi organ manusia dan hewan tertentu, kelainan/penyakit yang mungkin terjadi. Sedangkan kompetensi dasar yang dijadikan kajian penelitian, yaitu 1) Menjelaskan keterkaitan antara struktur, fungsi, dan proses yang meliputi pembentukan sel kelamin, ovulasi, menstruasi, fertilisasi, kehamilan, dan pemberian ASI serta kelainan/penyakit yang dapat terjadi pada sistem reproduksi manusia. Penelitian tindakan kelas ini dilaksanakan dalam dua siklus, dan masing-masing siklus terdiri dari empat tahapan, yaitu 1) perencanaan, 2) pelaksanaan tindakan, 3) observasi dan evaluasi tindakan, dan 4) refleksi (Arikunto, 2006). Siklus I dilaksanakan materi pokok organ Reproduksi pada Manusia, gametogenesis, hormon pasa sistem reproduksi, dan fertilisasi, sedangkan siklus II diterapkan pada materi pokok siklus menstruasi, kehamilan, gangguan pada Sistem Reproduksi dan cara penanggulangannya, serta alat kontrasepsi dan ASI. Untuk setiap siklus dirancang dalam 12 Jam pelajaran (2 kali tatap muka dan 1 kali evaluasi). Penelitian tindakan kelas ini dilaksanakan di pada tanggal 27 April sampai 12 Mei.

Penelitian tindakan kelas ini dilakukan di SMA Kosgoro Sekampung, Lampung pada semester genap tahun pelajaran 2011/2012. Subjek penelitiannya adalah siswa kelas XI IPA yang berjumlah 38 orang. Sedangkan objek penelitiannya adalah aktivitas dan hasil belajar.

Pada tahap perencanaan peneliti melakukan langkah-langkah 1) Menentukan kelas sebagai subjek penelitian, yaitu kelas XI IPA SMA Kosgoro Sekampung tahun pelajaran 2011/2012, 2) Menentukan materi pokok, yaitu Sistem Reproduksi pada manusia, 3) Membuat perangkat pembelajaran, yaitu silabus, RPP, kisikisi soal dan soal evaluasi, 4) Mempersiapkan media pembelajaran seperti buku biologi SMA kelas XI IPA dan sumber lain yang relevan dan LKS untuk melakukan pengamatan, 5) Membuat alat pengumpulan data berupa lembar observasi aktivitas siswa yang digunakan untuk melihat aktivitas siswa pada proses pembelajaran berlangsung dan tes soal evaluasi, 6) Membagi siswa kedalam 6 kelompok setiap kelompok terdiri dari 6-7 siswa yang heterogen.

Pelaksanaan tindakan pada prinsipnya merupakan realisasi dari suatu tindakan yang sudah direncanakan. Pada siklus I, materi pokok yang dikaji adalah organ Reproduksi pada Manusia, gametogenesis, hormon pasa sistem reproduksi, dan fertilisasi, yang dilaksanakan untuk dua kali tatap muka (8 x 45 menit). Sedangkan pada siklus II untuk materi pokok siklus menstruasi, 
kehamilan, gangguan pada Sistem Reproduksi dan cara penanggulangannya, serta alat kontrasepsi dan ASI yang dilaksanakan untuk dua kali tatap muka (8 $\mathrm{x} \quad 45$ menit).

\section{HASIL}

Berdasarkan hasil penelitian yang telah dilakukan, maka diperoleh gambaran umum tentang bagaimana penerapan model pembelajaran kooperatif tipe GI dapat meningkatkan hasil belajar siswa pada pokok bahasan Sistem Reproduksi. Data aktivitas belajar siswa selama proses pembelajaran dengan model pembelajaran kooperatif tipe GI.

Berdasarkan hasil tes evaluasi pada setiap akhir siklus I dan siklus II terdapat peningkatan hasil belajar siswa. Peningkatan hasil belajar tersebut dapat dilihat dalam Tabel 2.

Peningkatan hasil belajar siswa dalam penelitian yang dilakukan peneliti telah memenuhi target dalam penelitian ini, pada pra-PTK siswa yang mengalami ketuntasan sebesar 34,21\% sedangkan siswa yang belum tuntas sebesar 65,79\%. Pada siklus I penelitian siswa yang tuntas dengan KKㅆ 70 sebesar $68,42 \%$ dan siswa yang tidak tuntas sebesar $31,58 \%$ sedangkan pada siklus II siswa yang tuntas sebesar $81,58 \%$ dan siswa yang belum tuntas sebesar 18,42\%. Sedangkan peningkatan hasil belajar dari pra-PTK kesiklus II yaitu sebesar $47,37 \%$.

Tabel 2: Data Rata-rata Hasil Belajar Siklus I dan Siklus II

\begin{tabular}{|c|c|c|c|c|c|c|c|c|c|c|}
\hline \multirow{3}{*}{ No } & \multirow{3}{*}{ Ket } & \multirow{3}{*}{ KKM } & \multicolumn{3}{|c|}{ Banyak Siswa } & \multicolumn{3}{|c|}{ Persentase } & \multirow{2}{*}{\multicolumn{2}{|c|}{$\begin{array}{c}\text { Peningkatan } \\
\text { ketuntasan dari } \\
\text { Pra PTK-Siklus } \\
\text { II }\end{array}$}} \\
\hline & & & \multirow{2}{*}{$\begin{array}{l}\text { Pra } \\
\text { PTK }\end{array}$} & \multirow{2}{*}{$\begin{array}{c}\text { Siklus } \\
\text { I }\end{array}$} & \multirow{2}{*}{$\begin{array}{l}\text { Siklus } \\
\text { II }\end{array}$} & \multirow{2}{*}{$\begin{array}{l}\text { Pra } \\
\text { PTK }\end{array}$} & \multirow{2}{*}{$\begin{array}{l}\text { Siklus } \\
\text { I }\end{array}$} & \multirow{2}{*}{$\begin{array}{l}\text { Siklus } \\
\text { II }\end{array}$} & & \\
\hline & & & & & & & & & $\begin{array}{l}\text { Banyak } \\
\text { Siswa }\end{array}$ & (\%) \\
\hline 1 & Tuntas & $\geq 70$ & 13 & 26 & 31 & $\begin{array}{c}34,21 \\
\%\end{array}$ & $\begin{array}{c}68,42 \\
\%\end{array}$ & $\begin{array}{c}81,58 \\
\%\end{array}$ & & \\
\hline 2 & $\begin{array}{l}\text { Belum } \\
\text { Tuntas } \\
\end{array}$ & $<70$ & 25 & 12 & 7 & $\begin{array}{c}65,79 \\
\% \\
\end{array}$ & $\begin{array}{c}31,58 \\
\%\end{array}$ & $\begin{array}{c}18,42 \\
\%\end{array}$ & 18 & $\begin{array}{l}47,3 \\
7 \%\end{array}$ \\
\hline Jum & & & 38 & 38 & 38 & $100 \%$ & $100 \%$ & $100 \%$ & & \\
\hline
\end{tabular}

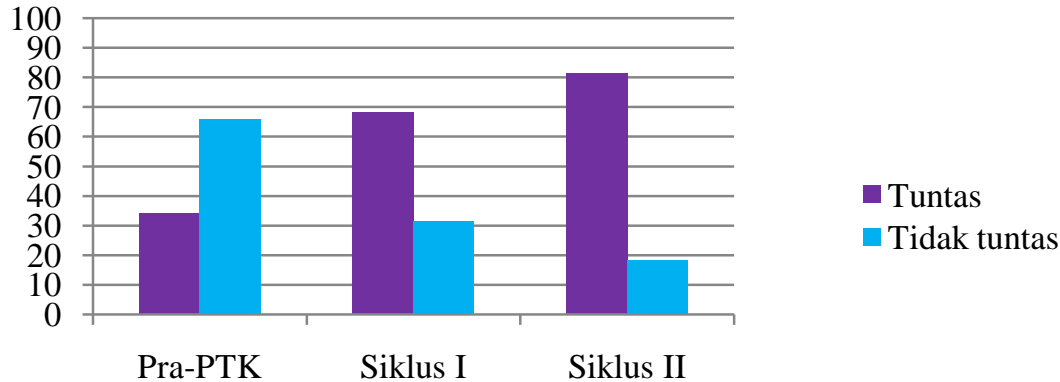

Gambar 1. Rata-Rata Hasil Belajar Siswa 


\section{PEMBAHASAN}

Penerapan model pembelajaran kooperatif tipe GI, mendapat respon yang postif dari siswa. Hal ini dapat dilihat dari aktivitas dan hasil belajar siswa mengalami peningkatan dari siklus I ke siklus II. Pembelajaran dengan model pembelajaran kooperatif tipe GI memberikan pembelajaran yang menyenangkan sebanding peningkatan hasil belajar yang diperoleh siswa pada setiap akhir siklus yang diberikan soal evaluasi. Aktivitas belajar sebagai "berbagai aktivitas yang diberikan pada pembelajar dalam situasi belajarmengajar”. Menurut Sardiman (2010:97), “dalam belajar sangat diperlukan adanya aktivitas belajar. Tanpa adanya aktivitas, belajar itu tidak mungkin akan berlangsung dengan baik". Aktivitas yang diamati dalam penelitian ini yaitu: mengerjakan latihan pada LKS, aktif berdiskusi dalam kelompok, memperhatikan penjelasan presentasi, bertanya atau mengemukakan pendapat, dan menyimpulkan hasil diskusi. Hal tersebut dibuktikan dengan peningkatan hasil belajar siswa pada siklus I dan peningkatan pula peda siklus II.

Dari hasil evaluasi siklus I siswa yang mengelami ketuntasan hasil belajar siswa $68,42 \%$ dan belum mencapai target yang ditentukan oleh sekolah, dan pada siklus II hasil belajar siswa yang mengelami ketuntasan mencapai 81,58\% target yang ditentukan oleh sekolah telah tercapai dengan ketuntasan belajar siswa lebih dari $75 \%$ siswa yang mengalami ketuntasan belajar. Hasil belajar merupakan tolak ukur keberhasilan pada proses pembelajaran. Hasil belajar dapat juga dikatakan sebagai hasil akhir dari proses pembelajaran serta merupakan perwujudan dari kemampuan diri yang optimal setelah menerima pembelajaran.
Menurut Sudjana (1991:22), hasil belajar memuat kemampuan yang dimiliki siswa setelah ia menerima pengalaman belajar. Sesuai dengan pendapat tersebut ketercapaian hasil belajar yang mengindikasikan pembelajaran yang dilaksanakan dengan model pembelajaran kooperatif tipe GI, memberikan dampak pembelajaran yang menyenangkan dan bermakna pada saat proses pembelajaran berlangsung denagan siswa yang aktif dalam pembelajaran sedangkan guru hanya berperan sebagai fasilitator sehingga dapat meningkatkan pemehaman siswa terhadap materi.

\section{KESIMPULAN DAN SARAN}

\section{Kesimpulan}

Berdasarkan hasil penelitian dan pembahasan dapat disimpulkan bahwa: Pembelajaran dengan penerapan model pembelajaran kooperatif tipe GI dapat meningkatkan hasil belajar siswa kelas XI IPA SMA Kosgoro Sekampung Tahun Pelajaran 2011/2012 mata pelajaran Biologi materi pokok Sistem Reproduksi pada Manusia.

\section{Saran}

Berdasarkan kesimpulan yang didapatkan dari hasil penelitian, maka peneliti memberikan saran dan pertimbangan pada guru atau pembaca yaitu: 1) Dalam model pembelajaran kooperatrif tipe GI untuk meningkatkan hasil belajar siswa dan dapat menjadi alternatif model pembelajaran yang digunakan dalam pembelajaran Biologi. 2) Dengan menggunakan model pembelajaran kooperatif tipe GI akan menumbuhkan rasa tanggung jawab serta mengembangkan pengetahuan dan pengalaman belajar akan menyenangkan 
bagi siswa. Dengan pembelajaran yang menyenangkan maka aktivitas belajar siswa akan meningkat serta proses belajar yang bermakna bagi siswa. Sedangkan peningkatan aktivitas belajar akan berpengaruh atas minat belajar dengan aktivitas belajar yang meningkat maka hasil belajar akan meningkat akibat sebuah proses pembelajaran.

\section{DAFTAR RUJUKAN}

Anderson,l. W. and Krathwohl, D. R. 2001. A Taxonomy for Learning, Teaching, and Assessing: A Revision of Bloom's Taxonomy of Educational Objectives. New York: Addison Wesley logman.

Arikunto, Suharsimi. 2006. Prosedur Penelitian Suatu Pendekatan Praktik. Jakarta: PT Rinika Cipta.

Lie, Anita. 2004. Cooperative Learning: Mempraktikan Cooperative Learning di Ruang-ruang Kelas. Jakarta: PT.Gramedia Widia Sarana Indonesia.

Rusman. 2010. Model-model Pembelajaran Mengembangkan Profesionalisme Guru. Jakarta: PT Rajagrafindo Persada.

Sanjaya, Wina. 2010. Strategi Pembelajaran Berorientasi Standar Proses Pendidikan. Jakarta: Kencana.

Sardiman. 2010. Intraksi dan Motivasi Belajar. Jakarta: Rajawali.

Slavin, R.E. 2010. Cooperative Learning Theory Research and Practice. Second Edition. Bandung: Nusa Media.
Sudjana, Nana. 1991. Penilaian Hasil Proses Belajar Mengajar. Bandung: Remaja Rosdakarya.

Suprijono, A. 2009. Cooperative Learning Teori dan Aplikasi Paikem. Yogyakarta: Pustaka Pelajar.

Trianto. 2010. Mendesain Model Pembelajaran Inovatif-Progresif. Jakarta: Kencana Prenada Media Group.

Universitas Muhammadiyah Metro. 2006. Pedoman Penulisan Karya Ilmiah. Metro: UM Metro. 
